\section{Effect of Prior Application of Desensitizing Agent on the Teeth Submitted to In-Office Bleaching}

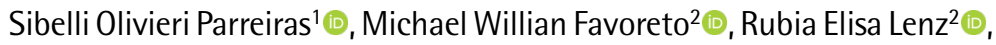
Maria Eduarda Serra ${ }^{3} \oplus$, Christiane Philippini Ferreira Borges $^{3} \oplus{ }^{\circ}$, Alessandro D. Loguercioº, Alessandra Reis² ${ }^{2}$

This study aimed to quantify the penetration of hydrogen peroxide, color change evaluation, surface morphology, and composition after application of desensitizing agents before in-office bleaching. Fifty premolars were sectioned, an acetate buffer was placed in the pulp chamber and divided into five groups $(n=10)$. In the positive control group, only the in-office bleaching gel was used, and in the negative control group, no treatment was used. Three different desensitizing agents were applied: Desensibilize KF2\% ${ }^{\circledR}$ group; Mi Paste ${ }^{\circledast}$ group, and Desensibilize Nano- $\mathrm{P}^{\circledast}$ group. The bleaching procedure was carried out with 35\% HP. The absorbance of the resulting solution was determined in a spectrophotometer. Color change was assessed by using a digital spectrophotometer. Four additional premolars were assigned to the same groups above for analysis under scanning electron microscope, as well as to evaluate the elemental composition with $\mathrm{X}$-ray dispersive energy spectrometry. Data were subjected to ANOVA and Tukey's test $(\alpha=0.05)$. All products reduced the penetration of HP in the pulp chamber. Mi Paste and Nano $P$ were the products that yielded the lowest HP penetration, which was similar to the negative control group $(p<0.001)$. No significant difference was detected in color change $(p<0.001)$. Concerning enamel morphology, the groups that were analyzed after bleaching were observed a greater deposition of desensitizing agents on the surface. The use of desensitizing agents before tooth bleaching seems to be an alternative to reduce adverse effects of the tooth.
'School of Dentistry, UENP Universidade Estadual do Norte do Paraná, Jacarezinho, PR, Brazil ${ }^{2}$ School of Dentistry, UEPG Universidade Estadual de Ponta Grossa, Ponta Grossa, PR, Brazil ${ }^{3}$ School of Chemistry, UEPG UniversidadeEstadual de Ponta Grossa, Ponta Grossa, PR, Brazil

Correspondence: Profa. Alessandra Reis, Avenida General Carlos Cavalcanti, 4748, Bloco M, 84030-900 Ponta Grossa, PR, Brasil. Tel: +55-42-3220-3000. e-mail: reis_ale@hotmail.com

Key Words: hydrogen peroxide, tooth bleaching, dentin desensitizing agents.

\section{Introduction}

Bleaching agents are commercially available to professional or home long-term use products. All these agents and components that contain peroxide break down into hydrogen peroxide (HP), which diffuses through the highly permeable interprismatic spaces in enamel and dentinal tubules, oxidizing the organic molecules. This oxidation alters the perception of color as light is reflected differently (1).

Unfortunately, due to its high oxidizing power, HP can cause side effects and modify the histological and morphological properties of the tooth structure (2). The penetration of the HP in the pulp chamber may result in DNA and cell damage (3) and may inhibit pulpal enzyme activity, resulting in an inflammatory process (4). Furthermore, HP may be responsible for the high risk of tooth sensitivity (TS) experienced by patients after in-office dental bleaching (5). To minimize this tooth sensitivity, manufacturers have added different compounds in bleaching products and clinicians have attempted to apply desensitizing agents before the bleaching session (6-17). The most used desensitizing agents are potassium nitrate, fluorides, casein phosphopeptides, amorphous calcium phosphate (CPP-
$\mathrm{ACP})$, and nano-calcium phosphate.

These desensitizing agents can reduce postoperative sensitivity through neural action or limit the amount of HP in the pulp. It is known that potassium nitrate penetrates the dental structure and when reaching the pulp it prevents nerve repolarization, and reduction of pain signal transmission to the central nervous systems $(18,19)$. On the other hand, other materials like fluorides, nano-calcium phosphate and CPP-ACP products, can act as a physical barrier, reducing the passage of hydrogen peroxide to the pulp (20).

Thus, they can minimize bleaching-induced TS by lowering the amount of HP that reaches the pulp chamber, and consequently, the pulp damage caused by the HP (14). To the extent of the author's knowledge, no study has attempted to investigate if desensitizing agents applied previously to in-office bleaching with 35\% HP can affect the amount of HP that reaches the pulp chamber. Therefore, the present study aimed to quantify the concentration of HP in the pulp chamber, color change evaluation, surface morphology, and composition after the application of desensitizing agents administered before an in-office bleaching. 
The null hypotheses tested were that the previous application of desensitizing agents before in-office tooth whitening would not affect [1] the amount of HP that reaches the pulp chamber of the groups submitted to desensitizing agents, [2] that the color change would not be so effective and [3] there would be no major changes in the surface.

\section{Material and Methods}

The Ethics Committee approved this study under protocol number 808.118. Fifty sound premolars were obtained from the Human Teeth Bank of the University. Enamel analysis of the specimens was performed using a stereomicroscope (Lambda LEB-3, ATTO instruments, Hong Kong, China) with 10x magnification. Specimens with morphological alterations or presence of enamel cracks were excluded.

\section{Sample Size Calculation}

The primary outcome of this study was the amount of HP that reached the pulp chamber. According to previous studies (21-23), the permeability of HP in the pulp chamber for the control group was determined to be $0.006 \pm 0.002 \mu \mathrm{g} / \mathrm{mL}$. Based on an alpha of 0.05 , a power of $80 \%$ and a two-side test, a minimum sample of six teeth in each group would be requires to detect a difference of $0.003 \mu \mathrm{g} / \mathrm{mL}$ between the groups tested. Considering, the possible loss of samples, ten samples were used for each group.

\section{Quantification of the Hydrogen Peroxide Concentration in the Pulp Chamber}

These specimens were randomly divided, by lottery, into five groups according to desensitizing agents to be used: 1) no desensitizing agent (positive control group); 2) Desensibilize KF 2\% (FGM, Joinville, SC, Brazil); 3) Mi
Paste (Corporation, Tokyo, Japan); 4) Desensibilize Nano-P (FGM). An additional negative control group, in which no bleaching treatment was performed, was added to the experimental design. Ten teeth were used for each group.

The roots of all teeth were cut approximately $3 \mathrm{~mm}$ apical to the cementoenamel junction, and the pulp tissue was removed and washed with distilled water. The entrance to the pulp cavities was widened carefully with a round bur \# 1014 (KG Sorensen, SP, Brazil) to allow the introduction of a micropipette (LABMATE Soft, HTL Lab Solutions, Warsaw, Poland) inside the pulp chamber.

Throughout this study, analytical-grade chemicals without previous purification were used; they were prepared with deionized water from a Millipore Milli-O system (MS2000) (Gehaka, SP, Brazil). We first plotted a standard reference line with a $5.000 \mu \mathrm{g} / \mathrm{mL}$ stock solution prepared from a concentrated solution (34-36\% hydrogen peroxide, LABSYNTH, Diadema, SP, Brazil) that was diluted in acetate buffer solution $(\mathrm{pH}=4.5)$ and standardized by conventional methods. The solution was titrated with standard potassium permanganate solution to determine its analytical grade and actual solution concentration (22). Based on this known initial concentration, we performed serial dilutions to plot the line. Thus, aliquots of the stock solution of HP were diluted volumetrically to obtain working standard solutions of $0.000-0.397 \mu \mathrm{g} / \mathrm{mL}$ (Table 1; Fig. 1) (22). The known concentrations of HP were added to the glass tubes and were placed in a Cary 50 UV-Vis spectrophotometer (Varian, Palo Alto, CA, USA). This procedure yielded a standard reference line for extrapolation of the results of the study samples (Fig. 1).

The specimens were fixed vertically to a wax plate with the occlusal face facing the plate. Before application of the bleaching agent, the labial surface of each specimen was isolated by applying a light-curable resin barrier enclosing

Table 1. Data points for the calibration curve

\begin{tabular}{|c|c|c|c|c|c|c|}
\hline \multicolumn{2}{|c|}{$\mathrm{H}_{2} \mathrm{O}_{2}$ Data For Each Point } & \multicolumn{5}{|c|}{ Solutions required to obtain $3000 \mu \mathrm{L}$ for Each Point for the Calibration Line } \\
\hline $\mathrm{H}_{2} \mathrm{O}_{2}$ weight, $\mu \mathrm{g}$ & $\begin{array}{c}\mathrm{H}_{2} \mathrm{O}_{2} \text { concentration, } \\
\mu \mathrm{g} / \mathrm{mL}\end{array}$ & $\begin{array}{l}\text { Acetate buffer } \\
\text { solution, } \mu \mathrm{L}\end{array}$ & $\begin{array}{c}47.67 \mu \mathrm{g} / \mathrm{mL} \mathrm{H}_{2} \mathrm{O}_{2} \\
\text { Solution, } \mu \mathrm{L}\end{array}$ & $\begin{array}{c}\text { Peroxidase, } \\
\mu \mathrm{L}\end{array}$ & $\begin{array}{l}\text { Leuco-crystal } \\
\text { violet, } \mu \mathrm{L}\end{array}$ & $\begin{array}{c}\text { Deionized } \\
\text { water, } \mu \mathrm{L}\end{array}$ \\
\hline 1.192 & 0.397 & 75 & 25 & 50 & 100 & 2750 \\
\hline 0.953 & 0.318 & 80 & 20 & 50 & 100 & 2750 \\
\hline 0.715 & 0.238 & 85 & 15 & 50 & 100 & 2750 \\
\hline 0.477 & 0.159 & 90 & 10 & 50 & 100 & 2750 \\
\hline 0.381 & 0.127 & 92 & 8 & 50 & 100 & 2750 \\
\hline 0.191 & 0.064 & 96 & 4 & 50 & 100 & 2750 \\
\hline 0.095 & 0.032 & 98 & 2 & 50 & 100 & 2750 \\
\hline 0.000 & 0.000 & 100 & 0 & 50 & 100 & 2750 \\
\hline
\end{tabular}


an area of $8 \mathrm{~mm}^{2}$ (Top dam, FGM). A $25 \mu \mathrm{L}$ aliquot of acetate buffer ( $\mathrm{pH}=4.5$ ) was placed into the pulp chamber of each tooth to absorb and stabilize any HP that might penetrate the pulp chamber.

The desensitizing agents were applied according to manufacturer's recommendations (Table 2). After that, we used the whitening gel Whiteness HP Maxx (FGM), composed of 35\% HP, thickeners, dye mixture, glycol, inorganic load, and deionized water. The bleaching gel was applied over the enamel surface by three applications of $15 \mathrm{~min}$ each. After the exposure period, the acetate buffer solutions in the pulp chamber of each tooth were removed using a mechanical micropipette (LABMATE Soft) and transferred to a glass tube. The pulp chamber of each tooth was rinsed four times with $25 \mu \mathrm{L}$ of acetate buffer, and this solution was removed from the pulp chamber and placed into the same glass tube. Sequentially, more deionized water $(2.725 \mu \mathrm{L})$ was added to the glass tube with $100 \mu \mathrm{L}$ of $0.5 \mathrm{mg} / \mathrm{mL}$ of leucocrystal violet (SigmaAldrich Chemie $\mathrm{GmbH}$, Steinheim, Germany) and $50 \mu \mathrm{L}$ of $1 \mathrm{mg} / \mathrm{mL}$ enzyme horseradish peroxidase (Peroxidase Type VI-A; Sigma-Aldrich Chemie GmbH).

The absorbance at $596 \mathrm{~nm}$ of the resultant violet

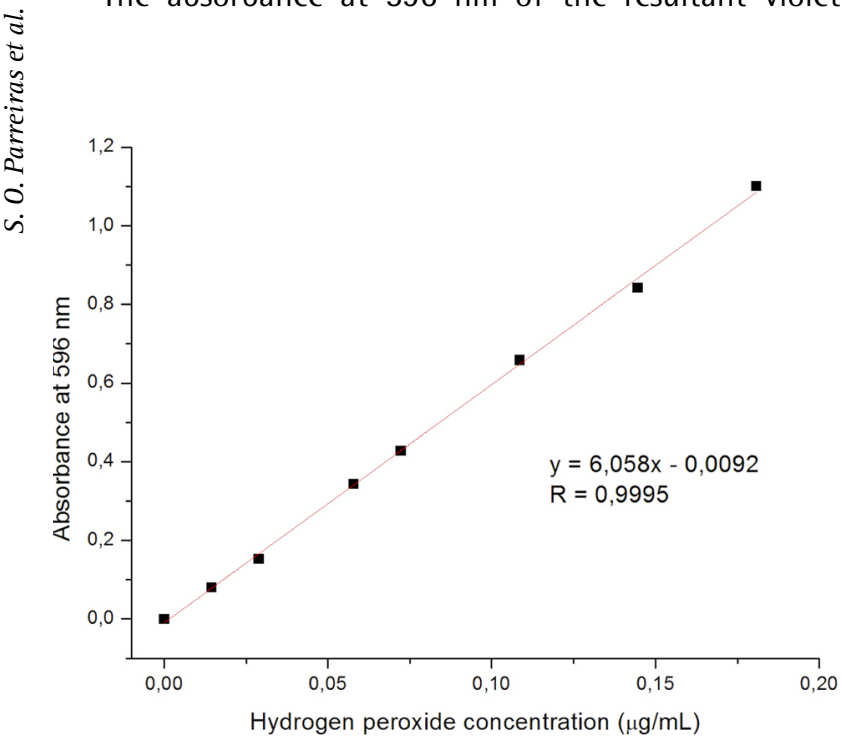

Figure 1. Spectrophotometric calibration curve used in this study, $\mathrm{R}=0.9995$. color in the tubes was measured in a Cary 50 UV- Vis spectrophotometer (Varian, Palo Alto, CA, USA). According to Beer's Law, absorbance is directly proportional to the concentration. Therefore, the concentration of HP $(\mu \mathrm{g} / \mathrm{mL})$ was determined by comparing it to the calibration curve previously obtained (Fig. 1).

\section{Evaluation of the Bleaching Efficacy}

The color change $(\Delta E)$ was measured before the treatments (specified earlier) and one week after the treatments with a spectrophotometer (VITA Easyshade Advance 4.0, VITA Zahnfabrik, Bad Säckingen, Germany). During this week, specimens were kept stored in artificial saliva, with daily changes at a controlled temperature of $37^{\circ} \mathrm{C}$.

For each specimen, a dense silicon paste (Coltoflax and Perfil Cub Kit, Vigodent, Rio de Janeiro, RJ, Brazil) mold was made to standardize the angle of measurement. For each tooth, we created a window on the buccal surface of the silicone guide, using a metal device with a radius of 6 millimeters, which is precisely the diameter of the tip of the spectrophotometer. The tip of the device was inserted into the silicone guide, and we obtained the $L^{*}, a^{*}$, and $b^{*}$ parameters of color from the spectrophotometer. The $L^{*}$ value represents the luminosity (value from 0 [black] to 100 [white]), $a^{*}$ value represents the measurement along the red-green axis, and $b^{*}$ value represents the measurement along the yellow-blue axis. The following expression calculated the overall color difference of the sample before (baseline) and one week after bleaching for each group: $\Delta \mathrm{E}=\left[\left(\Delta \mathrm{L}^{*}\right)^{2}+\left(\Delta \mathrm{a}^{*}\right)^{2}+\left(\Delta \mathrm{b}^{*}\right)^{2}\right]^{1 / 2}$.

The following expression calculated the whitening index for dentistry the sample before (baseline) and one week after bleaching for each group: $W I_{D}=\left(0.511 L^{*}\right)-\left(2.3424 a^{*}\right)$ - $\left(1.100 b^{*}\right)$. With this expression we can indicate if the samples are clearer when the highest values are presented; or they are darker when the values are lower (24). The baseline and final (after bleaching) whiteness index was calculated according to: $\Delta W I_{D}=W I_{D}$ after bleaching $-W I_{D}$ baseline.

Table 2. Composition and mode of application of the products used in this study

\begin{tabular}{ccc}
\hline Material [manufacturers] & Composition & Mode of Application \\
\hline Dessensibilize KF2\% [FGM, Brazil] & $\begin{array}{c}\text { Potassium nitrate 5\% and sodium fluoride 2\%, } \\
\text { deionized water, glicerin, and thickeners. }\end{array}$ & A single 10-min application \\
Mi Paste [GC Corp., Japan] & Casein phosphopeptide (CPP) and amorphous calcium phosphate (ACP). & A single 5-min application \\
Nano-P [FGM, Brazil] & $\begin{array}{c}9000 \mathrm{ppm} \text { fluoride sodium, 5\% potassium } \\
\text { nitrate, and nano-calcium phosphate. }\end{array}$ & A single 5-min application \\
Whiteness HP Maxx [FGM, Brazil] & $\begin{array}{c}\text { 35\% HP, thickeners, dye mixture, glycol, } \\
\text { inorganic load, and deionized water. }\end{array}$ & 3 application of 15 min each \\
\hline
\end{tabular}


Analysis of Enamel Surface Morphology and Dispersive Energy Spectrometry (EDS)

Four additional sound premolars were randomly selected, and five fragments of each tooth were obtained using a diamond disc at low speed with water irrigation (Isomet 1000, Buehler Ltd., Lake Bluff, IL, USA). Each fragment was exposed to the same treatments already described: 1) negative control group, 2) positive control group, 3) Desensibilize KF2\% group, 4) Mi Paste group, and 5) Desensibilize Nano-P group. After treatments, each sample was cleaned using ultrasonic bath with a frequency of $42 \mathrm{kHz}$ (Cristófoli Ultrasonic Washer, Campo Mourão, PR, Brazil) and then dehydrated in a desiccator containing colloidal silica for $24 \mathrm{~h}$ at $37^{\circ} \mathrm{C}$ and sputtercoated with $10 \mathrm{~nm}$ of gold before being taken to a low vacuum scanning electron microscope (SEM). To standardize image acquisition, we took three pictures of each specimen with a magnification of 10.000x in the secondary electron mode at $15 \mathrm{kV}$ (Mira 3- Tescan Orsay Holding, Warrendale, PA, USA). The first picture was taken in the center, and the other two pictures were taken $0.3 \mathrm{~mm}$ to the left, and right of the first one. A technician, blind to the experimental conditions, evaluated all the images, and selected the most representative one.

The same fragments above were subjected to composition analysis using energy dispersion spectroscopy (EDS), under $15.0 \mathrm{kV}$ voltage and $20.000 \times$ magnification. Calcium (Ca), phosphorus $(\mathrm{P})$, potassium $(\mathrm{K})$ and fluoride $(\mathrm{F})$ contents in mass percent were measured.

\section{Statistical Analysis}

Levene's test was used to test the assumption of equal variance, while the Shapiro-Wilk test was used to test the normal distribution of the data. Given these assumptions were observed, data related to HP concentration, color change in $\mathrm{DE}^{*}$ and $\mathrm{DWI}_{\mathrm{D}}$ values were subjected to one-way analysis of variance (ANOVA), followed by the Tukey's tests (alpha=0.05).

\section{Results}

The HP concentration that reached the pulp chamber in each group is depicted in Table 3. One-way ANOVA revealed statistically significant differences among the groups ( $p<0.001)$. No HP penetration was found in the negative control group, in which no HP was applied. In-office tooth bleaching without desensitizing agents (positive control group) caused the highest HP diffusion when compared to all the desensitizing agents. The lowest HP penetration was obtained for Mi Paste and Nano- $P(p<0.001)$.

The baseline measurements, color change $\Delta \mathrm{E}^{*}$ per group are described in Table 4. All groups where the bleaching was performed showed a mean color change statistically greater than the negative control group (without bleaching). A mean change of approximately 6 to 9 units of $\Delta \mathrm{E}^{*}$ observed, except the unbleached group. Among the desensitizing groups, no significant difference was detected among them $(p<0.001)$. Table 5 show mean and standard deviation values of $\Delta W I_{D}$ before and after bleaching for all experimental groups. $\Delta \mathrm{WI}_{\mathrm{D}}$ exhibited positive values and no differences in the whiteness index were detected between the groups subjected to 35\% HP ( $p>0.05)$.

Figure 2 shows the enamel morphology of all groups. A different superficial morphology was observed among the negative control group and specimens submitted to bleaching. Pronounced surface changes, irregularities, and demineralization were observed in the enamel submitted only to beaching (positive control group). Significant deposition of the desensitizers was observed on the enamel surfaces of the desensitizer groups due to the saturation of these products. The mineral analysis did

Table 3. Mean difference and confidence interval of the HP concentration $(\mu \mathrm{g} / \mathrm{mL})$ detected inside the pulp chamber for the experimental groups

\begin{tabular}{lccc}
\hline Groups & & Mean difference $(95 \% \mathrm{CI})$ & p-value \\
\hline \multirow{3}{*}{ Negative } & Positive Control & $-0.39(-0.58 \text { to }-0.21)^{*}$ & $<0.001$ \\
control & Mi Paste & $-0.05(-0.22$ to 0.11$)$ & 0.887 \\
& Desensibilize Nano P & $-0.04(-0.22$ to 0.14$)$ & 0.966 \\
& Negative Control & $0.39(0.21 \text { to } 0.58)^{*}$ & $<0.001$ \\
Positive & Desensibilize KF 2\% & $0.18(-0.00$ to 0.37$)$ & 0.063 \\
control & Mi Paste & $0.34(0.16 \text { to } 0.52)^{*}$ & $<0.001$ \\
& Desensibilize Nano P & $0.35(0.16 \text { to } 0.54)^{*}$ & $<0.001$ \\
\hline
\end{tabular}

${ }^{*}$ Mean difference is significant at the 0.05 level

Table 4. Mean and standard deviations of the baseline measurements, color change in $\Delta \mathrm{E}^{*}$ for all experimental groups

\begin{tabular}{|c|c|c|c|c|}
\hline \multirow{2}{*}{ Groups } & \multicolumn{3}{|c|}{ Baseline measurements } & \multirow{2}{*}{$\begin{array}{c}\text { Color } \\
\text { change } \\
\left(\Delta \mathrm{E}^{*}\right)\end{array}$} \\
\hline & $L^{*}$ & $a^{*}$ & $b^{*}$ & \\
\hline $\begin{array}{l}\text { Negative } \\
\text { control }\end{array}$ & $84.2 \pm 6.5$ & $-2.1 \pm 0.6$ & $22.1 \pm 3.3$ & $1.6 \pm 0.6 \mathrm{~A}$ \\
\hline $\begin{array}{l}\text { Positive } \\
\text { control }\end{array}$ & $85.4 \pm 3.8$ & $-1.6 \pm 2.0$ & $27.2 \pm 4.0$ & $9.3 \pm 1.6 \mathrm{~B}$ \\
\hline $\begin{array}{l}\text { Desensibilize } \\
\text { KF 2\% }\end{array}$ & $86.8 \pm 4.7$ & $-1.6 \pm 1.4$ & $24.9 \pm 4.6$ & $7.6 \pm 3.3 \mathrm{~B}$ \\
\hline Mi Paste & $85.7 \pm 5.8$ & $-2.1 \pm 1.2$ & $22.7 \pm 3.9$ & $6.7 \pm 1.9 \mathrm{~B}$ \\
\hline $\begin{array}{l}\text { Desensibilize } \\
\text { Nano-P }\end{array}$ & $83.5 \pm 3.8$ & $-0.4 \pm 1.4$ & $26.4 \pm 2.9$ & $8.8 \pm 2.8 \mathrm{~B}$ \\
\hline
\end{tabular}

Means identified with the same letters are statistically similar (p-value 0.05). 
not show any difference when EDS semi-quantification is performed (Table 6).

\section{Discussion}

The results of the present study confirmed the ability of HP to penetrate the tooth structure and reach the pulp chamber in a single in-office session. This finding has also been observed by an earlier study using the same methodology (21-23). However, we have also observed that a lower amount of HP was found when desensitizing agents were used before in-office dental bleaching.

The application of 5\% potassium nitrate and 2\% sodium fluoride (Desensibilize KF 2\%) before office bleaching reduced the concentration of HP in the pulp chamber by almost half compared to the positive control group. After removing the desensitizing gel, the fluoride ions would enhance crystal growth and increase the saturation of the enamel surface, delaying the dissolution of the minerals in the dental enamel, consequently, contribute to the repair of microstructural enamel defects $(20,25,26)$. Furthermore, the physical presence of fluoride over the enamel surface may reduce the passage of hydrogen peroxide ions to pulp (20).

Table 5. Mean and standard deviations values of whitening index $\left(\mathrm{WI}_{\mathrm{D}}\right)$ and color alteration $\left(\Delta \mathrm{WI}_{\mathrm{D}}\right)$ for all experimental groups

\begin{tabular}{lccc}
\hline \multirow{2}{*}{ Groups } & \multicolumn{2}{c}{ Whitening Index $\left(\mathrm{WI}_{\mathrm{D}}\right)$} & \multirow{2}{*}{$\Delta \mathrm{WI}_{\mathrm{D}}$} \\
\cline { 2 - 3 } & $\begin{array}{c}\text { Before } \\
\text { bleaching }\end{array}$ & $\begin{array}{c}\text { After } \\
\text { bleaching }\end{array}$ & \\
\hline Negative control & $23.5 \pm 5.6$ & $22.9 \pm 5.8$ & $-0.8 \pm 0.5 \mathrm{~A}$ \\
Positive control & $16.3 \pm 8.2$ & $30.7 \pm 6.4$ & $13.6 \pm 4.1 \mathrm{~B}$ \\
$\begin{array}{l}\text { Desensibilize } \\
\text { KF 2\% }\end{array}$ & $20.7 \pm 8.6$ & $30.6 \pm 7.7$ & $9.9 \pm 8.7 \mathrm{~B}$ \\
$\begin{array}{l}\text { Mi Paste } \\
\text { Desensibilize }\end{array}$ & $23.7 \pm 7.7$ & $33.8 \pm 6.3$ & $10.1 \pm 3.5 \mathrm{~B}$ \\
Nano-P & $14.7 \pm 2.2$ & $27.5 \pm 5.8$ & $12.8 \pm 5.8 \mathrm{~B}$ \\
\hline
\end{tabular}

Means identified with the same letters are statistically similar (p-value 0.05). dentifrices, and whitening materials applied to the external surface of the tooth can cross the enamel and dentin, and reach the pulp chamber (27), and this penetration is time dependent (19). It is known that potassium nitrate is related to the depolarization of the nerve fiber and the reduction of pain transfer $(18,19)$. It is speculated that a reaction may occur between potassium nitrate and hydrogen peroxide, thus contributing to a resistance in the passage of hydrogen peroxide to the pulp. However, more studies must be carried out in order to find interaction between these materials.

Not surprisingly, the level of HP in the pulp chamber of the CPP-ACP group was very low and similar to the specimens not bleached (negative control group). CPP$\mathrm{ACP}$ compounds have been shown to be superior to fluoride for remineralization of enamel (28). Besides, the use of CPP-ACP associated with fluoride was more effective in increasing the acid resistance of enamel from primary teeth than other fluoride varnishes (29). An in situ study demonstrated that the addition of 2\% CPP-ACP to $1100 \mathrm{ppm}-\mathrm{F}$, in a dentifrice, increased enamel subsurface remineralization by $156 \%$ relative to that produced by the $1100 \mathrm{ppm}-\mathrm{F}$ dentifrice alone (30).

The explanation for this superior performance is

Table 6. Means and standard deviations of calcium (\%), phosphorus $(\%)$, potassium $(\%)$ and fluorine $(\%)$ in enamel surfaces for the experimental conditions

\begin{tabular}{lcccc}
\hline $\begin{array}{l}\text { Experimental } \\
\text { groups }\end{array}$ & $\begin{array}{c}\text { Calcium } \\
(\%)\end{array}$ & $\begin{array}{c}\text { Phosphorus } \\
(\%)\end{array}$ & $\begin{array}{c}\text { Potassium } \\
(\%)\end{array}$ & $\begin{array}{c}\text { Fluorine } \\
(\%)\end{array}$ \\
\hline $\begin{array}{l}\text { Negative } \\
\text { control }\end{array}$ & $0.6 \pm 0.0$ & $0.5 \pm 0.0$ & $0.1 \pm 0.1$ & $0.7 \pm 0.0$ \\
$\begin{array}{l}\text { Positive } \\
\text { control }\end{array}$ & $0.6 \pm 0.1$ & $0.4 \pm 0.0$ & $0.0 \pm 0.0$ & $0.7 \pm 0.1$ \\
$\begin{array}{l}\text { Desensibilize } \\
\text { KF 2\% }\end{array}$ & $0.5 \pm 0.0$ & $0.4 \pm 0.0$ & $0.1 \pm 0.1$ & $0.6 \pm 0.1$ \\
$\begin{array}{l}\text { Mi Paste } \\
\text { Desensibilize }\end{array}$ & $0.6 \pm 0.0$ & $0.4 \pm 0.0$ & $0.2 \pm 0.0$ & $0.7 \pm 0.0$ \\
Nano-P & $0.5 \pm 0.1$ & $0.3 \pm 0.1$ & $0.1 \pm 0.0$ & $0.6 \pm 0.1$ \\
\hline
\end{tabular}

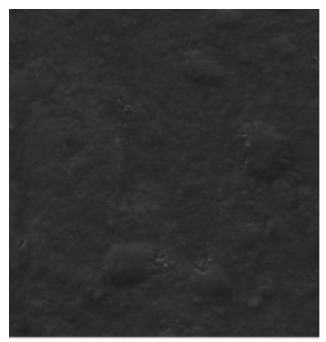

Negative control

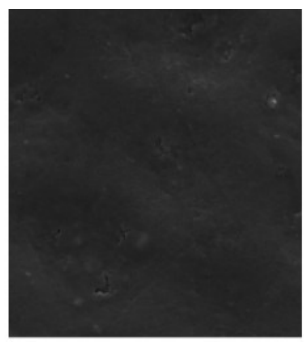

Positive control

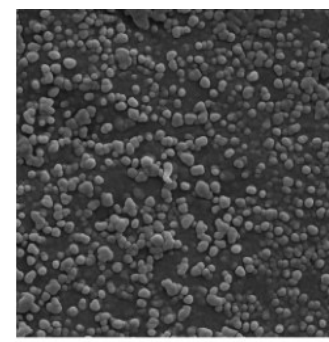

Desensibilize KF $2 \%$

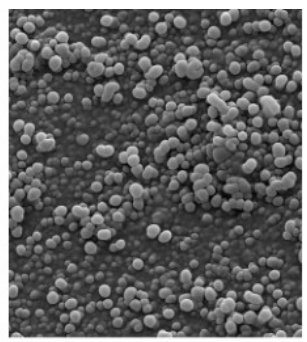

Mi Paste

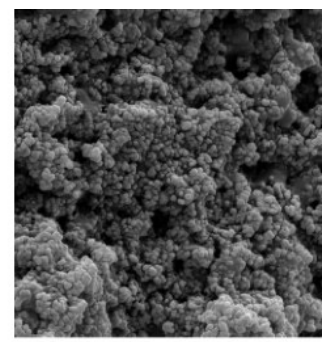

Desensibilize Nano P

Figure 2. Morphology of the enamel surface obtained in SEM at 10.000× magnification. 
based on the technology and composition of CPP-ACP materials. The CPP has been shown to stabilize calcium and phosphate, preserving them in an amorphous or soluble form termed as amorphous complexes (31). CPP, which contains the active sequence $\operatorname{Ser}(\mathrm{P})-\operatorname{Ser}(\mathrm{P})$ Ser(P)-Glu-Glu - has a remarkable ability to stabilize calcium and phosphate as nanoclusters of ions and ACPs exhibit a very high solubility and are readily converted to hydroxyapatite, which makes them suitable mineralizing agents (31). The application of CPP-ACP promoted the creation of a superficial mineral layer and an organized nanocluster, observed in figure 2 of this study.

Furthermore, CCP-ACP could compensate for any loss of flexural strength of the enamel and dentine complex during bleaching (32). In this context, we hypothesized that CPP-ACP could impose an important resistance in hard tissues to the penetration of the HP to the pulp chamber and, consequently, reduce the TS observed in some clinical studies $(7,11,16,17)$.

Concerning the nano-calcium phosphate paste, a lower amount of HP was observed in the pulp chamber, which was statistically similar to the negative control group and CPP-ACP group. It is important to emphasize that the Nano-P paste used in this study is composed of nano-calcium phosphate (in the form of hydroxyapatite), $9000 \mathrm{ppm}$ of fluoride, and 5\% potassium nitrate. Therefore, the reduction of the passage of HP may be attributed to several factors working together. As mentioned before, fluoride can form a physical barrier in tooth enamel and may be one of the reasons for the observed results.

According to the manufacturer's information, the synthetic hydroxyapatite, by being nanometric-sized, can penetrate more easily in enamel microcracks, can adhere to the surface of the tooth to cover grooves and pores on the enamel producing their occlusion (33). HP is liquid and therefore it is in a molecular state. On the other hand, calcium phosphate has low solubility and therefore it is in a suspension state as solid nanoparticles. Therefore, the probability of reaction is low. The very low amount of calcium phosphate that solubilizes increases the $\mathrm{pH}$ of the bleaching gel, making it less acidic and less prone to produce enamel demineralization. Additionally, hydroxyapatite nanoparticles can also precipitate onto the enamel surface, resulting in the formation of a new apatite layer $(12,34)$. As observed in this study, the application of the anhydrous calcium phosphate (NANO-P) reduced the enamel permeability significantly to HP and also created crystal precipitations on the enamel surface. This information may explain the ability of the product to reduce the concentration of HP in the pulp chamber.
Unfortunately, few studies in the literature have evaluated the effects of nano-calcium phosphate before dental bleaching, and those available reported conflicting results. Some authors demonstrated that the application of nano-hydroxyapatite product before dental bleaching did not reduce the risk and intensity of tooth sensitivity $(12,35)$, which is against the findings of the present investigation. In contrast, another study found reduced risk of bleaching-induced TS performed with 6\% HP gel containing 2\% nano-hydroxyapatite (36). This controversy between the laboratory results and the clinical results highlights the need for further studies on this topic.

Although we could observe, by SEM, the precipitation of the desensitizing agents on the enamel surface, the structural composition of the surfaces after treatments were not different to the non-bleached enamel. As enamel is composed by the same chemical elements of the desensitizers, the similarity of the superficial enamel composition was expected.

Regarding color change, the results of this study indicate that the preliminary application of the desensitizing gels did not influence the whitening effect. The findings by the index whitening in $\Delta W I_{D}$ analysis reaffirm an equivalent and significant color change in $\Delta \mathrm{E}^{*}$ was observed in all groups, except the unbleached group. The negative control group presented values so low that when calculating the delta $\Delta \mathrm{WI}$ the group presented negative values, in other words, low values are related to darker color (24). The results observed in this study were similar to the clinical studies reported in the literature (6-17). A small difference in color change $\Delta \mathrm{E}^{*}$ was observed in the negative control group. By removing the tooth from the storage medium and measuring color change with the device can cause subtle changes due to several factors, such as dehydration, repeatability and positioning errors even using a guide. However, we can also state that, for a significant lightening effect, a color change of $\Delta \mathrm{E}=1.2$ is considered within the perceptibility threshold and a color change of $\Delta \mathrm{E}=2.7$ is considered within the acceptability threshold (37). The color difference of 1.6 is within these two limits and therefore it is not clinically important.

The desensitizing agents, used in this study, can reduce the amount of HP that reaches the pulp chamber, without jeopardizing the whitening outcome. However, Mi Paste and Nano-P were the products that yielded the highest reduction of HP penetration, similar to the control group that received no bleaching treatment.

\section{Resumo}

Este estudo teve como objetivo quantificar a permeabilidade do 
peróxido de hidrogênio (PH), avaliação da mudança de cor, morfologia da superfície e composição de elementos após a aplicação de agentes dessensibilizantes antes do clareamento em consultório. Cinquenta pré-molares foram seccionados, um tampão de acetato foi colocado na câmara pulpar e divididos em cinco grupos $(n=10)$. No grupo controle positivo, apenas o gel clareador em consultório foi utilizado e no grupo controle negativo nenhum tratamento foi realizado. Foram aplicados três agentes dessensibilizantes diferentes: grupo KF2\% ${ }^{\circledR}$; grupo Mi Paste ${ }^{\circledR}$ e Desensibilize Nano- ${ }^{\circledR}$. 0 procedimento de clareamento foi realizado com PH a 35\%. A absorbância da solução resultante foi determinada em um espectrofotômetro. A mudança de cor foi avaliada utilizando um espectrofotômetro digital. Quatro pré-molares adicionais foram atribuídos aos mesmos grupos acima para análise em microscópio eletrônico de varredura, bem como para avaliar a composição elementar com espectrometria de energia dispersiva por raios-X. Os dados foram submetidos ao teste ANOVA e Tukey $(a=0,05)$. Todos os produtos reduziram a penetração de $\mathrm{PH}$ na câmara pulpar. Mi Paste e Nano $\mathrm{P}$ foram os produtos que apresentaram a menor penetração de $\mathrm{PH}$, semelhante ao grupo controle negativo $(p<0,001)$. Nenhuma diferença significativa foi detectada na mudança de cor $(p<0,001)$. Em relação à morfologia do esmalte, os grupos analisados após o clareamento apresentou maior deposição de agentes dessensibilizantes na superfície. 0 uso de agentes dessensibilizantes antes do clareamento dental parece ser uma alternativa para reduzir os efeitos adversos no dente.

\section{References}

1. Aschheim KW. Bleaching and related agents. Bleaching and related agents. 3rd ed. New York: CV Mosby; 2015.

2. Bersezio C, Estay J, Saez M, Sanchez F, Vernal R, Fernandez E. sixmonth follow-up of the effect of nonvital bleaching on il-1beta and rank-I: A randomized clinical trial. Oper Dent 2019;44:581-588.

3. Dias Ribeiro AP, Sacono NT, Lessa FC, Nogueira I, Coldebella CR, Hebling J, et al. Cytotoxic effect of a 35\% hydrogen peroxide bleaching gel on odontoblast-like MDPC-23 cells. Oral Surg Oral Med Oral Pathol Oral Radiol Endod 2009;108:458-464.

4. Vaz MM, Lopes LG, Cardoso PC, Souza JB, Batista AC, Costa NL, et al. Inflammatory response of human dental pulp to at-home and in-office tooth bleaching. J Appl Oral Sci 2016;24:509-517.

5. Rezende M, Loguercio AD, Kossatz S, Reis A. Predictive factors on the efficacy and risk/intensity of tooth sensitivity of dental bleaching: A multi regression and logistic analysis. J Dent 2016;45:1-6.

6. Bonafé $E$, Loguercio $A D$, Reis $A$, Kossatz $S$. Effectiveness of a desensitizing agent before in-office tooth bleaching in restored teeth. Clin Oral Investig 2014;18:839-845.

7. Oldoini G, Bruno A, Genovesi AM, Parisi L. Effects of amorphous calcium phosphate administration on dental sensitivity during inoffice and at-home interventions. Dent J 2018;6:1-6.

8. Palé M, Mayoral JR, Llopis J, Valles M, Basilio J, Roig M. Evaluation of the effectiveness of an in-office bleaching system and the effect of potassium nitrate as a desensitizing agent. Odontology 2014;102:203-210.

9. Tay LY, Kose C, Loguercio AD, Reis A. Assessing the effect of a desensitizing agent used before in-office tooth bleaching. J Am Dent Assoc 2009;140:1245-1251.

10. Mehta $D$, Venkata $S$, Naganath $M$, LingaReddy $U$, Ishihata $H$, Finger WJ. Clinical trial of tooth desensitization prior to in-office bleaching. Eur J Oral Sci 2013;121:477-481.

11. Yassin O, Milly H. Effect of CPP-ACP on efficacy and postoperative sensitivity associated with at-home vital tooth bleaching using 20\% carbamide peroxide. Clin Oral Investig 2019;23:1555-1559.

12. Loguercio AD, Tay LY, Herrera DR, Bauer J, Reis A. Effectiveness of nano-calcium phosphate paste on sensitivity during and after bleaching: a randomized clinical trial. Braz Oral Res 2015;29:1-7.

13. de Paula B, Alencar C, Ortiz M, Couto R, Araujo J, Silva C. Effect of photobiomodulation with low-level laser therapy combined with potassium nitrate on controlling post-bleaching tooth sensitivity: clinical, randomized, controlled, double-blind, and split-mouth study. Clin Oral Investig 2019;23:2723-2732.

14. Reis A, Dalanhol AP, Cunha TS, Kossatz S, Loguercio AD. Assessment of tooth sensitivity using a desensitizer before light-activated bleaching. Oper Dent 2011;36:12-17.

15. Maghaireh GA, Alzraikat H, Guidoum A. Assessment of the effect of casein phosphopeptide-amorphous calcium phosphate on postoperative sensitivity associated with in-office vital tooth whitening. Oper Dent 2014;39:239-247.

16. Alexandrino LD, Alencar CM, Silveira A, Alves EB, Silva CM. Randomized clinical trial of the effect of NovaMin and CPP-ACPF in combination with dental bleaching. J Appl Oral Sci 2017;25:335340 .

17. Grobler SR, Majeed A, Moola MH, Rossouw RJ, van Wyk Kotze T. In vivo spectrophotometric assessment of the tooth whitening effectiveness of nite white $10 \%$ with amorphous calcium phosphate, potassium nitrate and fluoride, over a 6-month period. Open Dent J 2011:5:18-23.

18. Markowitz K. Pretty painful: why does tooth bleaching hurt? Med hypotheses 2010;74:835-840.

19. Kwon SR, Dawson DV, Wertz PW. Time course of potassium nitrate penetration into the pulp cavity and the effect of penetration levels on tooth whitening efficacy. J Esthet Restor Dent 2016;28:14-22.

20. Torres C, Zanatta RF, Silva TJ, Borges AB. Effect of calcium and fluoride addition to hydrogen peroxide bleaching gel on tooth diffusion, color, and microhardness. Oper Dent 2019;44:424-432.

21. Mena-Serrano AP, Parreiras SO, do Nascimento EM, Borges $C P_{1}$ Berger $\mathrm{SB}$, Loguercio $A D$, et al. Effects of the concentration and composition of in-office bleaching gels on hydrogen peroxide penetration into the pulp chamber. Oper Dent 2015;40:76-82.

22. Parreiras $S$, Mena-Serrano A, Moreira CG, Otuki M, Loguercio D, Reis A. Penetration and cytotoxicity of a bleaching gel activated by LED/ laser in restored teeth. Am J Dent 2014;27:301-306.

23. Acunã ED, Parreiras SO, Favoreto MW, Cruz GP, Gomes A, Borges $\mathrm{CPF}$, et al. In-office bleaching with a commercial $40 \%$ hydrogen peroxide gel modified to have different $\mathrm{pHs}$ : Color change, surface morphology, and penetration of hydrogen peroxide into the pulp chamber. J Esthet Restor Dent 2019.31:1-6.

24. Perez Mdel M, Ghinea R, Rivas MJ, Yebra A, lonescu AM, Paravina RD, et al. Development of a customized whiteness index for dentistry based on CIELAB color space. Dent Mater 2016;32:461-467.

25. de Oliveira $R$, Paes Leme $A F$, Giannini $M$. Effect of a carbamide peroxide bleaching gel containing calcium or fluoride on human enamel surface microhardness. Braz Dent J 2005;16:103-106.

26. White DJ, Nancollas GH. Physical and chemical considerations of the role of firmly and loosely bound fluoride in caries prevention. J Dent Res 1990;69:587-594.

27. Kwon SR, Dawson DV, Schenck DM, Fiegel J, Wertz PW. Spectrophotometric evaluation of potassium nitrate penetration into the pulp cavity. Oper Dent 2015;40:614-21.

28. Hay KD, Thomson WM. A clinical trial of the anticaries efficacy of casein derivatives complexed with calcium phosphate in patients with salivary gland dysfunction. Oral Surg Oral Med Oral Pathol Oral Radiol Endod 2002;93:271-275.

29. Schemehorn BR, Wood GD, McHale W, Winston AE. Comparison of fluoride uptake into tooth enamel from two fluoride varnishes containing different calcium phosphate sources. J Clin Dent 2011;22:51-54.

30. Reynolds EC. Casein phosphopeptide-amorphous calcium phosphate: the scientific evidence. Adv Dent Res 2009;21:25-29.

31. Gurunathan D, Somasundaram S, Kumar S. Casein phosphopeptideamorphous calcium phosphate: a remineralizing agent of enamel. Aust Dent J 2012;57:404-408.

32. Khoroushi M, Mazaheri $H$, Manoochehri A. Effect of CPP-ACP application on flexural strength of bleached enamel and dentin complex. Oper Dent 2011;36:372-379.

33. Kim B, Jeong S, Jang S, Kim KN, Kwon H, Park YD. Tooth whitening effect of toothpastes containing nano-hydroxyapatite. Key Eng Mater 2006;309:541-544. 
34. Huang S, Gao S, Yu H. Effect of nano-hydroxyapatite concentration on remineralization of initial enamel lesion in vitro. Biomed mater 2009;4:034104.

35. Browning WD, Cho SD, Deschepper EJ. Effect of a nanohydroxyapatite paste on bleaching-related tooth sensitivity. J Esthet Restor Dent 2012;24:268-276.
36. Vano M, Derchi G, Barone A, Genovesi A, Covani U. Tooth bleaching with hydrogen peroxide and nano-hydroxyapatite: a 9-month follow-up randomized clinical trial. Int J Dent Hyg 2015;13:301-307.

37. Paravina $R D$, Ghinea $R$, Herrera $\amalg$, Bona $A D$, Igiel $C$, Linninger $M$, et al. Color difference thresholds in dentistry. J Esthet Restor Dent 2015;27:1-9.

Received January 10, 2020

Accepted April 7, 2020 